\title{
Glacimarine sedimentation processes at Kronebreen and Kongsvegen, Svalbard
}

\author{
Laura M. KEHRL, ${ }^{1 *}$ Robert L. HAWLEY, ${ }^{1}$ Ross D. POWELL, ${ }^{2}$ Julie BRIGHAM-GRETTE ${ }^{3}$ \\ ${ }^{1}$ Department of Earth Sciences, Dartmouth College, HB 6105 Fairchild Hall, Hanover, New Hampshire 03755-3571, USA \\ E-mail: laura.kehrl@vuw.ac.nz \\ ${ }^{2}$ Department of Geology and Environmental Geosciences, Northern Illinois University, DeKalb, Illinois 60119, USA \\ ${ }^{3}$ Department of Geosciences, University of Massachusetts, 611 North Pleasant Street, Amherst, \\ Massachusetts 01003-9297, USA
}

\begin{abstract}
Tidewater glaciers deposit sediment at their terminus, thereby reducing the relative water depth. Reduced water depth can lead to increased glacier stability through decreased rates of iceberg calving, glacier thinning and submarine melting. Here we investigate sedimentation processes at the termini of Kronebreen and Kongsvegen, Svalbard. We mapped the fjord floor bathymetry in August 2009 and calculate sedimentation rates based on our bathymetry and that from a similar study in 2005 . A grounding-line fan is developing near the current position of the subglacial stream. An older, abandoned grounding-line fan that likely formed between $\sim 1987$ and 2001 is degrading near the middle of the ice front. Our findings indicate that sediment gravity flows reduce the height of the sediment mound forming at the glacier terminus. The future impact of glacimarine sedimentation processes on glacier stability will depend on the net balance between the observed gravity flows and sediment deposition.
\end{abstract}

\section{INTRODUCTION}

Tidewater glaciers often appear decoupled from the climate system (Mercer, 1961; Warren, 1992). Many studies attribute this behavior to a relationship between fjord floor bathymetry and glacier stability at the terminus. Glacimarine sediment deposition alters the fjord floor bathymetry by reducing relative water depth at the glacier terminus (Powell, 1991). As water depth at the terminus decreases, iceberg calving rates tend to decrease because of reduced glacier buoyancy and thinning rates (Benn and others, 2007). The sediment also protects the submarine face from melting by fjord waters (Powell, 1991), which is currently considered a prime driver of rapid retreat on marineterminating glaciers in Greenland and Antarctica (e.g. Holland and others, 2008; Rignot and others, 2010). Since calving and submarine melting are the dominant ablation mechanisms for most tidewater glaciers, reduced water depth due to sediment deposition can help stabilize a glacier at a particular location if sediment accumulation rates are sufficiently high. Conversely, if a glacier retreats from its deposited sediment mound and enters deeper water, rapid retreat may occur due to increased calving rates and greater exposure to oceanic melt. Retreat will continue until the glacier reaches shallower water again (Meier and Post, 1987; Oerlemans and Nick, 2006) or the retreat slows sufficiently to allow rapidly accumulated sediment to drive the terminus toward stability (Powell, 1991; Hunter and others, 1996b).

As a result, the rate at which sediment accumulates at the glacier terminus determines the potential impact of sediment deposition on glacier stability (Hunter and others, 1996b). In fact, the temperate glacier systems in Alaska, with their very high sediment accumulation rates, have even demonstrated terminus advance after sufficient sediment accumulated during a slowing of retreat (Powell, 1991). Colder, polythermal glaciers, such as Kronebreen and Kongsvegen,

*Present address: Antarctic Research Centre, Victoria University of Wellington, PO Box 600, Wellington, New Zealand.
Svalbard, have fewer studies of near-terminus sediment accumulation rates than their counterparts in Alaska and consequently are not as well understood in terms of their ability to self-regulate their stability. In this study, we quantify sediment accumulation rates and processes from 2005 to 2009 at the termini of Kronebreen and Kongsvegen. This will enable future work to assess how these glaciers might respond to sedimentation processes in the future. We calculate sedimentation rates by comparing measured water depths from 2009 to those recorded in 2005 by Trusel and others (2010).

\section{STUDY SITE: KRONEBREEN AND KONGSVEGEN}

Kongsfjorden is located in western Spitsbergen, Svalbard $\left(79^{\circ} \mathrm{N}, 12^{\circ} \mathrm{E}\right.$; Fig. 1). Many glaciers calve into Kongsfjorden, including the $444 \mathrm{~km}^{2}$ Kronebreen and $163 \mathrm{~km}^{2}$ Kongsvegen at the fjord's head (Hagen and others, 1993). Kronebreen and Kongsvegen converge $\sim 5 \mathrm{~km}$ from their joint tidewater terminus. The glacier complex reached its maximum Holocene extent during the Little Ice Age (LIA; Liestøl, 1988). Since then, the ice front has been in retreat, interrupted by short periods of advance due to surge events (Melvold and Hagen, 1998). Kronebreen last surged in 1869; at the end of the surge, the terminus extended $\sim 10-11 \mathrm{~km}$ beyond its present-day position (Melvold and Hagen, 1998; Svendsen and others, 2002). The complex again advanced from 1936 to 1948 when Kongsvegen surged (Woodward and others, 2002). Once Kongsvegen returned to a quiescent state, the complex retreated again, reaching its current position in the mid-1980s (Melvold and Hagen, 1998). Kronebreen, which is one of the fastest-flowing glaciers in Svalbard $\left(750 \mathrm{~m} \mathrm{a}^{-1}\right.$ $\sim 5 \mathrm{~km}$ from its terminus; Melvold and Hagen, 1998), now dominates the confluent tidewater cliff.

The nearby fjord floor morphology reflects the retreatadvance cycles of Kronebreen, Kongsvegen and nearby glaciers since the late Weichselian (20ka BP; Howe and others, 2003; Ottesen and others, 2007; McLachlan and 


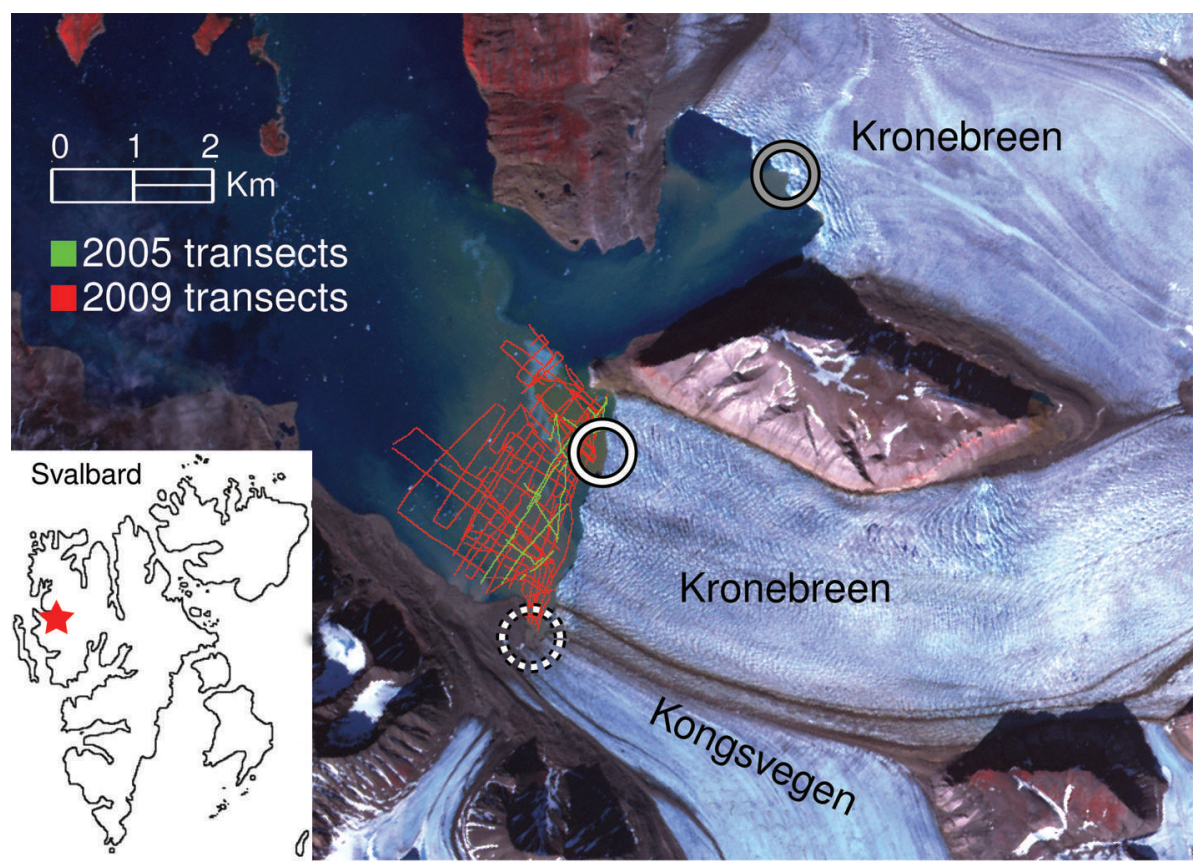

Fig. 1. Map of the study site. Kronebreen and Kongsvegen terminate at the head of Kongsfjorden (red star in inset; $79^{\circ} \mathrm{N}, 12^{\circ} \mathrm{E}$ ). Two point sources deliver sediment to the complex's terminus: an ice-marginal stream (dashed white circle) and a subglacial stream (solid white circle). The gray circle indicates a subglacial stream that emerged between Landsat images taken on 30 June and 7 July 2002 . All three sediment sources form plumes that extend into the fjord. Green and red lines indicate 2005 and 2009 echo-sounding transects, respectively.

others, 2011). In outer and central Kongsfjorden, ice-scoured bedrock uncovered during the glacial readvances of the Weichselian and the LIA is now covered by up to $10 \mathrm{~m}$ of sediment (Howe and others, 2003). Relict drumlins and flutes are common in the central fjord (Howe and others, 2003). At the head of the fjord near Kronebreen and Kongsvegen, morainal banks mark the maximum glacial extents of the 1869 and 1948 surge events (Whittington and others, 1997).

Glacimarine sedimentation processes continue to shape the fjord floor. Two point sources supply sediment to the fjord floor adjacent to the glacier complex: (1) a subglacial stream that exits Kronebreen just north of the center line and (2) an ice-marginal stream that flows alongside the southern margin of Kongsvegen (Fig. 1). Sedimentation rates are greatest near the ice cliff $\left(>100 \mathrm{~mm} \mathrm{a}^{-1}\right)$ and decrease with distance to $50-100 \mathrm{~mm} \mathrm{a}^{-1} \sim 10 \mathrm{~km}$ away from the terminus (Elverhøi and others, 1980, 1983). Iceberg-rafted debris delivers up to an additional $8 \mathrm{~mm} \mathrm{a}^{-1}$ in inner Kongsfjorden (Dowdeswell and Dowdeswell, 1989). About $90 \%$ of the total sediment input is deposited within $400 \mathrm{~m}$ of the ice front, thereby decreasing water depth at the grounding line (Elverhøi and others, 1983; Svendsen and others, 2002).

\section{METHODS}

\subsection{Mapping the fjord floor}

We recorded a series of echo-sounding transects adjacent to Kronebreen and Kongsvegen in August 2009 with a Knudsen $320 \mathrm{BP}$ depth sounder using frequencies of 28 and $200 \mathrm{kHz}$ (Fig. 1). To geolocate our transects, we used a hand-held GPS to mark waypoints every 1-2 min. We interpolated between waypoints to determine the location of intermediate points. Transects were a rough grid, with spacing of 200$300 \mathrm{~m}$. In total, our transects covered a study area of $6 \mathrm{~km}^{2}$ 100-200 $\mathrm{m}$ away from the glacier terminus.
We used the SounderSuite software package by Knudsen to determine fjord floor depth from the recorded echograms. We then adjusted the measured fjord floor depth for tides recorded by the Norwegian Hydrographic Service in NyÅlesund and applied a fourth-order Butterworth smoothing filter to remove the small, apparent undulations in the fjord floor surface that occur due to surface waves. Finally, we used a triangle-based linear interpolation to construct a three-dimensional model of the fjord floor.

Water depths for 2009 are shown in Figure 2. Water depth increases away from the ice front to $\sim 100 \mathrm{~m}$ at a distance of $1 \mathrm{~km}$. A ridge (60-70 m water depth) extends parallel to the ice front $\sim 300-500 \mathrm{~m}$ from the ice. Two bathymetric highs ( $\sim 40 \mathrm{~m}$ water depth) lie along the ridge, which we label $A$ and $B$ in Figure 2, following the notation of Trusel and others (2010).

In order to evaluate the precision of our depth measurements, we exploit the fact that our measurement transects from the same campaign cross over one another. We call these 'precision crossover points'. At a precision crossover point, the actual depth must be the same, but the measured depths, $z_{1}, z_{2}$, may vary. The difference, $c=\left|z_{1}-z_{2}\right|$, between the measured depths gives us our level of confidence in our depth measurements at that location. Precision crossover differences, $c$, are shown in Figure 3. In both years, we typically find $c<5 \mathrm{~m}$ near the subglacial upwelling and $c>5 \mathrm{~m}$ near the ice-marginal stream and in areas of high relief. Mean crossover differences, $\bar{c}$, are greater for $2005(\bar{c}=5.5 \pm 5.9 \mathrm{~m})$ than $2009(\bar{c}=2.3 \pm 4.3 \mathrm{~m})$. These values are calculated from 25 and 241 crossover differences in 2005 and 2009, respectively.

\subsection{Calculating sediment accumulation rates}

To calculate sediment accumulation rates, we compare our measured water depths from 2009 to water depths recorded in 2005 by Trusel and others (2010). Their study, which used 


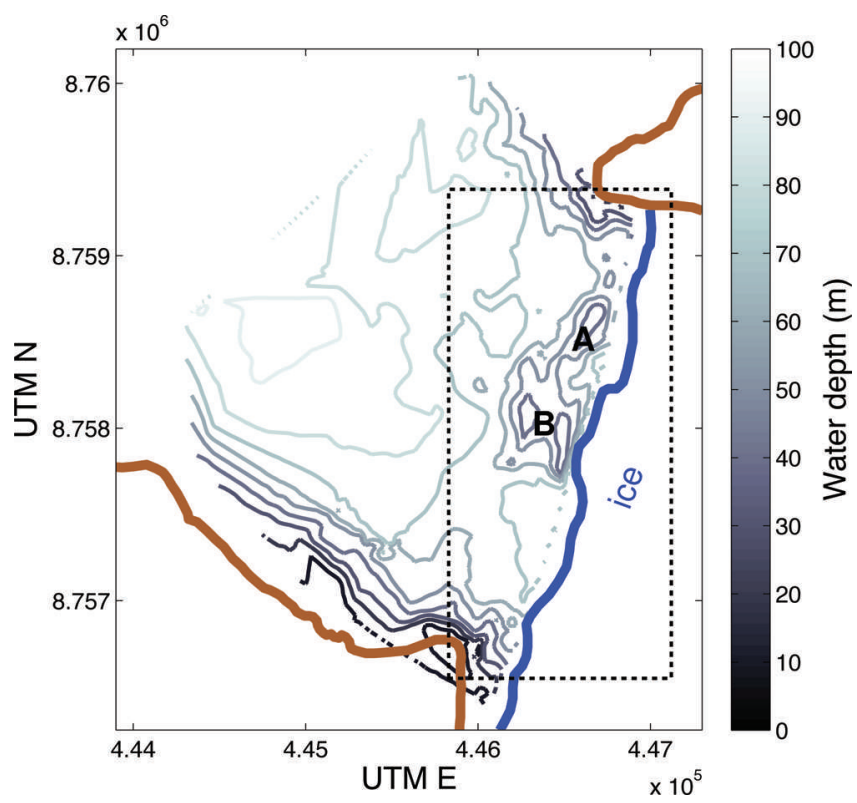

Fig. 2. Bathymetry in 2009. A ridge extends parallel to the ice front $\sim 300-500 \mathrm{~m}$ from the terminus. Two bathymetric highs lie along the ridge, labeled $\mathrm{A}$ and $\mathrm{B}$, following the notation of Trusel and others (2010). The dashed box indicates the region shown in Figure 5.

the same echo-sounding equipment and software, covered a smaller area $\left(2 \mathrm{~km}^{2}\right)$ near the ice front with greater spacing between transects (300-500 m; Fig. 1). We calculate sedimentation rates at crossovers between 2005 and 2009 transects. We call these 'sedimentation crossover points'. This technique eliminates potential errors introduced by interpolation.

At some sedimentation crossover points, we are not confident in the accuracy of our data from one of the years. We are confident in our data when $c<1 \mathrm{~m}$ (see section 3.1). Precision crossover differences, $c$, are only defined at precision crossover points, but we wish to calculate sedimentation rates at sedimentation crossover points. To account for this, we only report calculated rates for sedimentation crossover points within $300 \mathrm{~m}$ (the average spacing between transects) of a $c<1 \mathrm{~m}$ precision crossover point from each year. This process is illustrated in Figure 4.

To assess the error of our calculated rates, we compute $\bar{C}$ for all 2005 and 2009 precision crossover differences within $300 \mathrm{~m}$ of a given sedimentation crossover point. The sum of $\bar{c}$ for 2005 and 2009 divided by the time duration (4 years) represents the maximum error that we would expect for the rate at that location.

\subsection{Mapping subglacial upwelling position}

In order to determine the sedimentation processes active since the glacier complex became stable in its present position in the mid-1980s, we mapped the location of the sediment plumes using satellite imagery from 1987 to 2009. The location of the plume reflects the location of a major sediment source, so a change in its position impacts the fjord morphology.

We determined sediment plume position using a combination of the red $(630-740 \mathrm{~nm})$ and green $(520-600 \mathrm{~nm})$ bands in cloud-free Landsat 4-7, Système Probatoire pour I'Observation de la Terre (SPOT) and Advanced Spaceborne

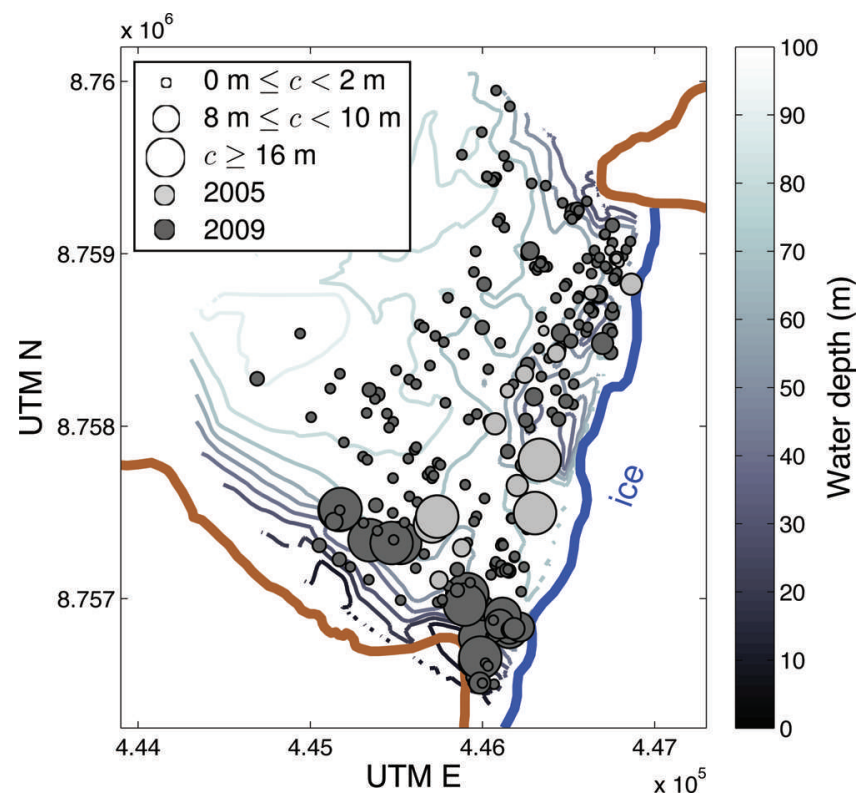

Fig. 3. Precision crossover differences for 2005 (light gray) and 2009 (dark gray). Size of the dot indicates the magnitude of the precision crossover difference (0-20 m). Contours are fjord bathymetry (Fig. 2). Precision crossover differences are largest near the ice-marginal stream and in areas of steep topography. Values decrease near the subglacial stream and with distance from the grounding line.

Thermal Emission and Reflection Radiometer (ASTER) imagery. Suspended sediment is particularly reflective in the red spectrum, allowing for clear delineation between sediment-rich and clear waters (e.g. Miller and McKee,

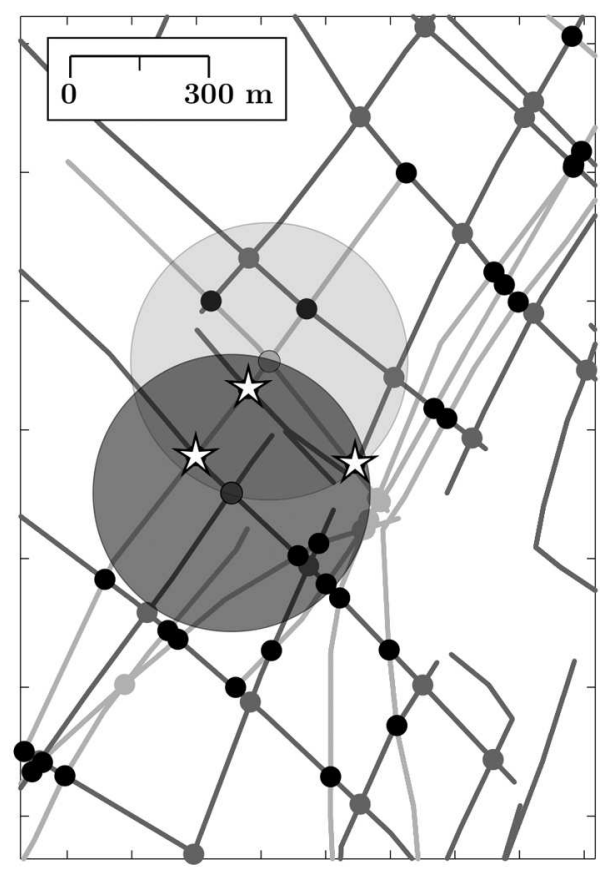

Fig. 4. We calculate sediment accumulation rates where we are confident in our measured water depths from both years. Light and dark gray dots indicate 2005 and 2009 precision crossovers points, respectively. Black dots indicate sedimentation crossover points. The shaded light and dark gray circles indicate the $300 \mathrm{~m}$ limit for a $c<1 \mathrm{~m}$ crossover point for 2005 and one for 2009. We consider sedimentation crossover points where these circles overlap (indicated by the stars). Results from this analysis are plotted in Figure 6. 


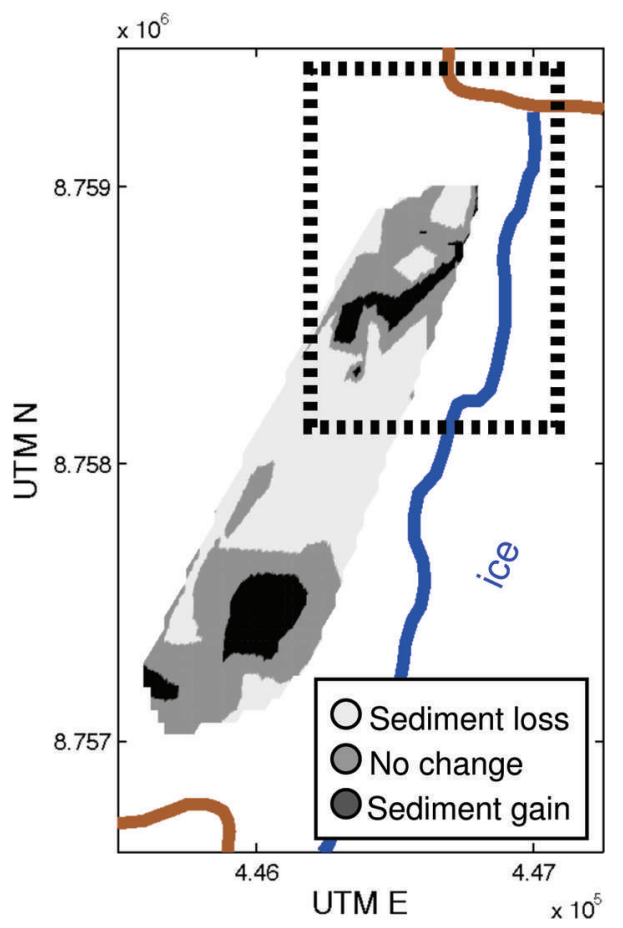

Fig. 5. Sediment accumulation rates computed from all sedimentation crossover points. Light gray indicates sediment loss, medium gray indicates no change, and black indicates sediment deposition. We find sediment deposition near the subglacial upwelling and icemarginal stream, and sediment loss near the center of the ice front. The dashed box indicates the region shown in Figure 6 .

2004; Chu and others, 2009). However, the sediment-rich waters originating from the subglacial and ice-marginal streams have a similar spectral signature in the red band, which makes it difficult to differentiate between the two sediment plumes. In the green band, the plumes' spectral reflectances differ, likely due to differences in sediment color. We therefore utilized the red band to differentiate between clear and sediment-rich water, and the green band to delineate the plume of interest in the sediment-rich water.

We considered any location along the ice front in contact with the upwelling sediment plume as a possible location of the subglacial upwelling source. The fresh water exiting the subglacial stream is far more buoyant than the surrounding cold, saline water, so the plume water will rise directly to the surface in front of the glacier (Powell and Molnia, 1989; Syvitski, 1989). As a result, to map the subglacial upwelling position, we mapped the portion of the ice cliff in contact with the upwelling sediment plume over time. As this methodology did not depend on sediment plume extent, it eliminated the need to correct for tides, wind and meltwater discharge (Dowdeswell and Cromack, 1991; Willis and others, 1996; Chu and others, 2009).

\section{RESULTS}

\subsection{Sediment accumulation rates}

Sediment accumulation rates from 2005 to 2009 are shown in Figures 5 and 6 and Table 1. To show the regional-scale sedimentation pattern, we plot the rates from all sedimentation crossover points, regardless of the magnitude of the nearby precision crossover differences, in Figure 5. We have interpolated rates between these points with a triangle-based
Table 1. Sediment accumulation rates shown in Figure 6 , by Universal Transverse Mercator (UTM) zone 33X coordinates

\begin{tabular}{lll}
\hline UTM N UTME & Rate \\
$\mathrm{ma}^{-1}$
\end{tabular}

\begin{tabular}{|c|c|c|}
\hline 8758594 & 446385 & $0.30 \pm 0.08$ \\
\hline 8758509 & 446494 & $-0.84 \pm 0.13$ \\
\hline 8758517 & 446484 & $1.00 \pm 0.13$ \\
\hline 8758700 & 446462 & $-0.65 \pm 0.08$ \\
\hline 8758623 & 446530 & $0.28 \pm 0.11$ \\
\hline 8758940 & 446800 & $1.00 \pm 0.27$ \\
\hline 8758599 & 446549 & $-0.22 \pm 0.12$ \\
\hline 8758972 & 446809 & $1.69 \pm 0.29$ \\
\hline 8758941 & 446801 & $1.14 \pm 0.27$ \\
\hline 8758778 & 446764 & $0.94 \pm 0.26$ \\
\hline 8758613 & 446538 & $1.35 \pm 0.11$ \\
\hline 8758532 & 446340 & $0.83 \pm 0.09$ \\
\hline 8758865 & 446518 & $0.49 \pm 0.18$ \\
\hline 8758806 & 446591 & $-0.28 \pm 0.23$ \\
\hline 8758600 & 446311 & $-0.27 \pm 0.08$ \\
\hline 8758474 & 446423 & $-1.56 \pm 0.10$ \\
\hline 8759045 & 446716 & $-1.00 \pm 0.28$ \\
\hline 8759007 & 446752 & $-2.86 \pm 0.29$ \\
\hline 8758694 & 446619 & $-0.95 \pm 0.14$ \\
\hline 8759010 & 446753 & $-2.58 \pm 0.29$ \\
\hline 8759044 & 446715 & $-1.09 \pm 0.28$ \\
\hline 8758716 & 446598 & $-1.65 \pm 0.14$ \\
\hline 8758905 & 446721 & $-2.97 \pm 0.22$ \\
\hline 8758903 & 446764 & $-2.24 \pm 0.23$ \\
\hline 8758918 & 446732 & $-2.76 \pm 0.22$ \\
\hline 8758704 & 446592 & $-2.73 \pm 0.14$ \\
\hline 8758685 & 446613 & $-1.09 \pm 0.14$ \\
\hline 8758879 & 446748 & $-2.38 \pm 0.26$ \\
\hline 8758706 & 446592 & $-1.63 \pm 0.14$ \\
\hline 8758910 & 446726 & $-2.69 \pm 0.22$ \\
\hline 8759033 & 446821 & $-1.49 \pm 0.26$ \\
\hline 8758270 & 446455 & $-0.65 \pm 0.10$ \\
\hline 8758412 & 446395 & $0.42 \pm 0.10$ \\
\hline 8758329 & 446358 & $1.54 \pm 0.10$ \\
\hline 8758384 & 446229 & $-2.40 \pm 0.09$ \\
\hline 8758480 & 446300 & $2.03 \pm 0.09$ \\
\hline 8758231 & 446404 & $-2.27 \pm 0.12$ \\
\hline 8758369 & 446411 & $-1.70 \pm 0.08$ \\
\hline 8758161 & 446472 & $-0.15 \pm 0.13$ \\
\hline 8758329 & 446449 & $-0.69 \pm 0.08$ \\
\hline 8758337 & 446286 & $-3.36 \pm 0.11$ \\
\hline 8758402 & 446379 & $2.09 \pm 0.10$ \\
\hline 8758380 & 446400 & $-0.45 \pm 0.10$ \\
\hline 8758300 & 446330 & $-0.84 \pm 0.11$ \\
\hline 8758344 & 446278 & $-2.94 \pm 0.10$ \\
\hline 8758814 & 446653 & $0.68 \pm 0.25$ \\
\hline
\end{tabular}

linear interpolation to a regular grid. On a regional scale, sediment was deposited near the subglacial and icemarginal streams and lost near bathymetric high B.

Our precision crossover differences for 2005 and 2009 (Fig. 3) indicate that our uncertainty is too high to provide an accurate estimate of a net annual sediment accumulation rate for this region. The best estimate we can provide is a range in order of magnitude, which is $10^{4}-10^{5} \mathrm{~m}^{3} \mathrm{a}^{-1}$. As this estimate only covers an area that extends $\sim 500 \mathrm{~m}$ from the glacier terminus, it is likely that the total sediment deposited by these glaciers is greater when the entire depositional grounding-line system is taken into account.

It is possible with our data, however, to obtain local, onedimensional net annual accumulation and erosion rates with 
much higher reliability at particular points where our precision crossover differences show we have greater accuracy. In Figure 6 and Table 1, we report calculated sedimentation rates only in regions with precision crossover differences less than $1 \mathrm{~m}$, following the methodology outlined in Figure 4. All calculated rates are located near the subglacial upwelling. The maximum calculated sediment loss $\left(-3.36 \pm 0.11 \mathrm{~m} \mathrm{a}^{-1}\right)$ was located near bathymetric high $\mathrm{B}$. The maximum gain $\left(2.09 \pm 0.10 \mathrm{~m} \mathrm{a}^{-1}\right)$ was located downslope of that loss. In general, we find sediment loss near bathymetric highs and sediment gain downslope of those losses.

\subsection{Subglacial upwelling position}

The position of the subglacial stream changed between 1987 and 2009. From 1987 to 2001, the subglacial upwelling was located near the middle of the ice front ( $B$ in Fig. 2). The upwelling then moved $400-500 \mathrm{~m}$ north (A in Fig. 2) between Landsat images taken on 30 June and 7 July 2002. On 30 June, the sediment plume extended across the ice front, covering both the current (A) and past (B) positions of the subglacial upwelling. On 7 July, the plume was localized near its present-day position, A. Over the same period, a new subglacial upwelling emerged from a more northern toe of Kronebreen (gray circle in Fig. 1).

\section{DISCUSSION}

The fjord floor morphology adjacent to Kronebreen and Kongsvegen reflects both past and present sedimentation processes. A ridge rising 30-70 $\mathrm{m}$ above the $100 \mathrm{~m}$ fjord floor extends parallel to the calving front $\sim 300-500 \mathrm{~m}$ from the ice cliff. This feature likely represents a push moraine from the seasonal advance of the terminus during winter, when calving is decreased (Elverhøi and others, 1980; Trusel and others, 2010). Retreat and push moraines have been documented nearby in Borebukta by Ottesen and Dowdeswell (2006).

We interpret bathymetric highs $A$ and $B$ along the ridge (Fig. 2) as grounding-line fans as noted by Trusel and others (2010). Over the period $\sim 1987-2001$, the subglacial upwelling was located near B. Bathymetric high B likely formed during this time. Since 2002, the upwelling has been stable in its present position near A, likely forming bathymetric high A.

The observed sediment accumulation rates from 2005 to 2009 support our interpretation of the fjord morphology. We find sediment loss near the past position of the subglacial upwelling, indicating that the grounding-line fan at B is currently degrading. Near the current position of the subglacial upwelling, we find sediment accumulation more than $1 \mathrm{~m} \mathrm{a}^{-1}$, indicating that the grounding-line fan at $A$ is currently forming. Our rate at this location is much higher than those reported by Elverhøi and others (1980) $\left(>0.100 \mathrm{~m} \mathrm{a}^{-1}\right.$ near the ice front) and Trusel and others (2010) $\left(>0.06 \mathrm{~m} \mathrm{a}^{-1}\right.$ within $0.5 \mathrm{~km}$ of the subglacial stream). It is likely that our rate differs from those of other studies primarily because of different measurement techniques, with the previous measurements relying largely on singlepoint data. Trusel and others (2010) had only one bathymetry dataset and therefore extrapolated an hourly sediment trap rate to a 'conservative' 60 day melt period to determine an annual rate. Elverhøi and others (1980) determined their annual rate from a sediment core. Our results also indicate

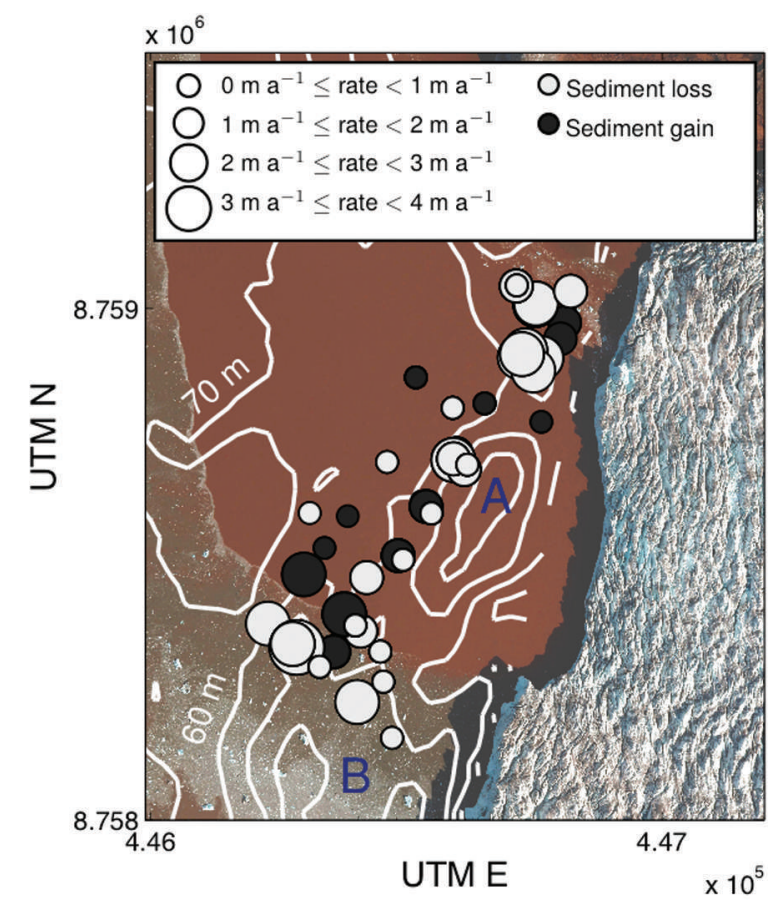

Fig. 6. Sediment accumulation rates in regions of precision crossover agreement less than $1 \mathrm{~m}$, following the process outlined in Figure 4. Black and white dots indicate sediment gain and loss, respectively. The size of the dot indicates the magnitude of the change (0-4 $\left.\mathrm{m} \mathrm{a}^{-1}\right)$. Contours are 2009 fjord bathymetry, and labels $A$ and $B$ correspond to those in Figure 2. We generally find sediment loss near bathymetric highs, and sediment gain downslope of those losses. Background image is a subset of aerial photograph S2009 18222_00784 by Norsk Polarinstitutt.

sediment deposition near the ice-marginal stream from 2005 to 2009 (Fig. 5), contributing to the Gilbert-type delta there noted by Trusel and others (2010).

Near the subglacial upwelling, sedimentation rates also vary locally. In general, sediment was lost from bathymetric highs and redeposited downslope of the areas of loss (Fig. 6). We interpret these redepositional events as mass movements, primarily sediment gravity flows moving sediment downslope. Such flows are common in regions with high sedimentation rates because the sediment does not have time to dewater before more sediment accumulates; the inclusion of water lowers the stable angle of repose, so redeposition becomes more likely. Mass failures can also result from disturbances caused by iceberg calving or glacier pushing during winter advance (Powell, 1981). Foreslope angles along the ridge $\left(10-20^{\circ}\right)$ are similar to values observed for glacimarine sediments on the Antarctic Peninsula (15-18 ; Larter and Barker, 1989) and in Alaska (12-15 ; Powell, 1981). If the observed slope angles are close to the angle of repose for the sediment, the $30-50 \mathrm{~m}$ seasonal advance of the ice front during winter (Elverhøi and others, 1983) could push the morainal bank, causing oversteepening and slope failures. Trusel and others (2010) observed turbidites in a sediment trap located near bathymetric high B that were compositionally similar to those in the grounding-line fan.

We also find sediment loss $\left(<0.7 \mathrm{~m} \mathrm{a}^{-1}\right)$ in low-slope $\left(<10^{\circ}\right)$ areas that must not have been over-steepened by pushing (Fig. 6). These areas are beyond the limit of iceberg scouring, which in inner Kongsfjorden is $40 \mathrm{~m}$ water depth (Dowdeswell and Forsberg, 1992). However, sediment loss 
may have resulted from iceberg calving events or by mass sediment failures propagating from further upslope (cf. Powell, 1981).

Our results suggest that sediment gravity flows are important in determining the distribution of sediment near Kronebreen and Kongsvegen. This is similar to what has been found for temperate glacial systems in Alaska (Hunter and others, 1996a). Through redepositing sediment downslope, sediment gravity flows tend to lower the morainal bank forming at the glacier grounding line. We might expect the depocenter to take longer to build because of this lowering process. Therefore, estimates of basin infilling from sediment trap measurements likely underestimate the time it will take the basin to fill, as they do not take into account losses due to gravity flows (cf. Hunter and others, 1996b; Cai and others, 1997). As yet, data are too sparse in the study area to quantify the total volume of sediment redeposited to more distal locations from the grounding line. If sediment gravity flows are redeposited more locally, then the ice-proximal basin will fill faster than if the flows travel to greater distances.

\section{CONCLUSIONS}

The fjord floor morphology adjacent to Kronebreen and Kongsvegen reflects the nearby sedimentation processes originating from the glaciers. We find sediment accumulation rates more than $1 \mathrm{~m} \mathrm{a}^{-1}$ near the current position of the subglacial stream, indicating the formation of a groundingline fan. Our calculated accumulation rates are greater than previous estimates (Elverhøi and others, 1980; Trusel and others, 2010). As we calculated our rates based on the net sediment balance between 2005 and 2009, it is possible that the sediment accumulation rates from the subglacial stream are actually much higher when loss mechanisms are removed from the analysis. We also find a degrading, relict grounding-line fan that likely formed between $\sim 1987$ and 2001 near the center of the ice front.

The net sediment accumulation rate near the glacier terminus determines the rate at which water depth is reduced and therefore reflects the potential impact of glacimarine sedimentation processes on glacier stability. We show that sediment gravity flows decrease the sediment height near the glacier terminus. If the sediment gravity flows redeposit sediment locally, they will not affect the rate at which water depth is reduced. However, if they redeposit sediment more distally, the flows will reduce the net sedimentation rate at the glacier terminus and thereby decrease the stabilizing effect of sedimentation (Powell, 1991).

\section{ACKNOWLEDGEMENTS}

We thank Norsk Polarinstitutt and the University Centre in Svalbard for logistical support in the field. We also thank Scientific Editor J. Hart, M. Forwick and an anonymous reviewer, for insightful comments that improved the manuscript. This work was supported by the US National Science Foundation REU program through grant 0649006.

\section{REFERENCES}

Benn, D.I., C.W. Warren and R.H. Mottram. 2007. Calving processes and the dynamics of calving glaciers. Earth-Sci. Rev., 82(3-4), 143-179.
Cai, J.K., R.D. Powell, E.A. Cowan and P.R. Carlson. 1997 Lithofacies and seismic-reflection interpretation of temperate glacimarine sedimentation in Tarr Inlet, Glacier Bay, Alaska. Mar. Geol., 143(1-4), 5-37.

Chu, V.W., L.C. Smith, A.K. Rennermalm, R.R. Forster, J.E. Box and N. Reeh. 2009. Sediment plume response to surface melting and supraglacial lake drainages on the Greenland ice sheet. J. Glaciol., 55(194), 1072-1082.

Dowdeswell, J.A. and M. Cromack. 1991. Behavior of a glacierderived suspended sediment plume in a small Arctic inlet. J. Geol., 99(1), 111-123.

Dowdeswell, J.A. and E.K. Dowdeswell. 1989. Debris in icebergs and rates of glaci-marine sedimentation: observations from Spitsbergen and a simple model. J. Geol., 97(2), 221-231.

Dowdeswell, J.A. and C.F. Forsberg. 1992. The size and frequency of icebergs and bergy bits derived from tidewater glaciers in Kongsfjorden, northwest Spitsbergen. Polar Res., 11(2), 81-91.

Elverhøi, A., O. Liestøl and J. Nagy. 1980. Glacial erosion, sedimentation and microfauna in the inner part of Kongsfjorden, Spitsbergen. Nor. Polarinst. Skr., 172, 33-61.

Elverhøi, A., Ø. Lønne and R. Seland. 1983. Glaciomarine sedimentation in a modern-fjord environment, Spitsbergen. Polar Res., 1(2), 127-149.

Hagen, J.O., O. Liestøl, E. Roland and T. Jørgensen. 1993. Glacier atlas of Svalbard and Jan Mayen. Nor. Polarinst. Medd. 129.

Holland, D.M., R.H. Thomas, B. de Young, M.H. Ribergaard and B. Lyberth. 2008. Acceleration of Jakobshavn Isbræ triggered by warm subsurface ocean waters. Nature Geosci., 1(10), 659-664.

Howe, J.A., S. Moreton, C. Morri and P. Morris. 2003. Multibeam bathymetry and the depositional environments of Kongsfjorden and Krossfjorden, western Spitsbergen, Svalbard. Polar Res. 22(2), 301-316.

Hunter, L.E., R.D. Powell and D.E. Lawson. 1996a. Flux of debris transported by ice at three Alaskan tidewater glaciers. J. Glaciol., 42(140), 123-135.

Hunter, L.E., R.D. Powell and D.E. Lawson. 1996b. Morainal-bank sediment budgets and their influence on the stability of tidewater termini of valley glaciers entering Glacier Bay, Alaska, U.S.A. Ann. Glaciol., 22, 211-216.

Larter, R.D. and P.F. Barker. 1989. Seismic stratigraphy of the Antarctic Peninsula Pacific margin: a record of PliocenePleistocene ice volume and paleoclimate. Geology, 17(8), 731-734.

Liestøl, O. 1988. The glaciers in the Kongsfjorden area, Spitsbergen. Nor. Geogr. Tidsskr., 42(4), 231-238.

MacLachlan, S.E., J.A. Howe and M.E. Vardy. 2011. Morphodynamic evolution of Kongsfjorden-Krossfjorden, Svalbard, during the Late Weichselian and Holocene. In Howe, J.A., W.E.N. Austin, M. Forwick and M. Paetzel, eds. Fjord systems and archives. London, Geological Society, 195-205. (GSL Special Publication 344.)

Meier, M.F. and A. Post. 1987. Fast tidewater glaciers. J. Geophys. Res., 92(B9), 9051-9058.

Melvold, K. and J.O. Hagen. 1998. Evolution of a surge-type glacier in its quiescent phase: Kongsvegen, Spitsbergen, 1964-95. J. Glaciol., 44(147), 394-404.

Mercer, J.H. 1961. The response of fjord glaciers to changes in the firn limit. J. Glaciol., 3(29), 850-858.

Miller, R.L. and B.A. McKee. 2004. Using MODIS Terra $250 \mathrm{~m}$ imagery to map concentrations of total suspended matter in coastal waters. Remote Sens. Environ., 93(1-2), 259-266.

Oerlemans, J. and F.M. Nick. 2006. Modelling the advance-retreat cycle of a tidewater glacier with simple sediment dynamics. Global Planet. Change, 50(3-4), 148-160.

Ottesen, D. and J.A. Dowdeswell. 2006. Assemblages of submarine landforms produced by tidewater glaciers in Svalbard. J. Geophys. Res., 111(F1), F01016. (10.1029/2005JF000330.)

Ottesen, D., J.A. Dowdeswell, J.Y. Landvik and J. Mienert. 2007. Dynamics of the Late Weichselian ice sheet on Svalbard inferred 
from high-resolution sea-floor morphology. Boreas, 36(3), 286-306.

Powell, R.D. 1981. A model for sedimentation by tidewater glaciers. Ann. Glaciol., 2, 129-134.

Powell, R.D. 1991. Grounding-line systems as second-order controls on fluctuations of tidewater termini of temperate glaciers. In Glacial marine sedimentation; paleoclimatic significance. Boulder, CO, Geological Society of America, 75-93. (GSA Special Paper 261.)

Powell, R.D. and B.F. Molnia. 1989. Glacimarine sedimentary processes, facies and morphology of the south-southeast Alaska Shelf and fjords. Mar. Geol., 85(2-4), 359-390.

Rignot, E., M. Koppes and I. Velicogna. 2010. Rapid submarine melting of the calving faces of West Greenland glaciers. Nature Geosci., 3(3), 141-218.

Svendsen, H. and 14 others. 2002. The physical environment of Kongsfjorden-Krossfjorden, an Arctic fjord system in Svalbard. Polar Res., 21(1), 133-166.

Syvitski, J.P.M. 1989. On the deposition of sediment within glacierinfluenced fjords: oceanographic controls. Mar. Geol., 85(2-4), 301-329.
Trusel, L.D., R.D. Powell, R.M. Cumpston and J. Brigham-Grette. 2010. Modern glacimarine processes and potential future behaviour of Kronebreen and Kongsvegen polythermal tidewater glaciers, Kongsfjorden, Svalbard. In Howe, J.A., W.E.N. Austin, $M$. Forwick and M. Paetzel, eds. Fjord systems and archives. London, Geological Society, 89-102. (GSL Special Publication 344.) Warren, C.R. 1992. Iceberg calving and the glacioclimatic record. Progr. Phys. Geogr., 16(3), 253-282.

Whittington, R.J., C.F. Forsberg and J.A. Dowdeswell. 1997. Seismic and side-scan sonar investigations of recent sedimentation in an ice-proximal glacimarine setting, Kongsfjorden, northwest Spitsbergen. In Davies, T.A. and 7 others, eds. Glaciated continental margins: an atlas of acoustic images. London, Chapman \& Hall, 175-178.

Willis, I.C., K.S. Richards and M.J. Sharp. 1996. Links between proglacial stream suspended sediment dynamics, glacier hydrology and glacier motion at Midtdalsbreen, Norway. Hydrol. Process., 10(4), 629-648.

Woodward, J., T. Murray and A. McCaig. 2002. Formation and reorientation of structure in the surge-type glacier Kongsvegen, Svalbard. J. Quat. Sci., 17(3), 201-209.

MS received 14 January 2011 and accepted in revised form 5 June 2011 